\title{
JOURNAL.RU
}

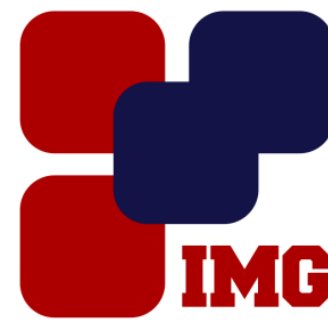
IVANOY Management GROUP

Сычева О.С. Ростовский институт (филиал) ФГБ ОУ ВО «Всероссийский государственный университет юстиции (РПА Минюста России)» Ростов-на-Дону, Россия

doi: $10.18411 / 1 \mathrm{j}-30-04-2017-3-15$

idsp 000001:1j-30-04-2017-3-15

\section{Правовая природа и сущность деловой репутации юридических лиц}

В России процесс формирования и дальнейшего развития деловой репутации юридического лица как объекта гражданских прав был довольно длительным. Большинство существовавших в нашей стране законодательных актов на разных исторических этапах предполагали только защиту интересов физических лиц, связанных с формированием именно их положительной деловой репутации, деловая репутация юридических лиц нормативными актами не затрагивалась.

Причинами тому были, во-первых, отсутствие реальных отношений, которые нуждались бы в правовой регламентации, а также в отсутствии правомочий, которые требовали бы признания со стороны окружающих, и требований, которые не были связаны с защитой как таковой. Во-вторых, неготовность и неспособность права повлиять на ход развития данных неимущественных отношений и их дальнейшую коммерциализацию.

Репутация - полноправный нематериальный актив и поэтому формирование, управление ею, а также использование в качестве инструмента в условиях конкурентной борьбы, становится все более актуальным в наше время.

Действующее гражданское российское законодательство относит деловую репутацию к нематериальным благам. Она является единственным поименованным в Гражданском Кодексе РФ благом, принадлежащим юридическому лицу и существующим исключительно в сфере предпринимательства. Положительное общественное мнение о деловых качествах и профессиональной деятельности юридического лица или 
индивидуального предпринимателя является одним из условий успешной деятельности и обладает бесспорной значимостью. Репутация во многом определяет возможности юридического лица в привлечении средств, поиска стратегических инвесторов и партнеров, оперативности управления, которое может обеспечить построение отношений с властью, формировании спроса и лояльности потребителей.

Следует обратить внимание на то, что в соответствии со статьей 150 Гражданского Кодекса РФ деловая репутация относится к нематериальным благам. Передача её в использование другим лицам, а также экономическая оценка закреплены в статье 1027 Гражданского Кодекса РФ, регулирующей договор коммерческой концессии. Она устанавливает право использования одной стороной (пользователем) деловой репутации другой стороны (правообладателя) и вследствие этого допускает влияние «стоимости» деловой репутации на стоимость передаваемых исключительных прав.

Помимо этого, законодательством нашей страны предусмотрено, что деловая репутация может быть отчуждена третьему лицу в составе предприятия по договору купли-продажи (статья 132 ГК РФ).

В статье 1042 Гражданского Кодекса РФ, например, предусмотрено право товарища вносить в общее дело деньги, иное имущество, профессиональные и иные знания, навыки и умения, а также деловую репутацию и деловые связи.

Следовательно, деловую репутацию субъектов предпринимательской деятельности смело можно отнести к нематериальным активам, которые могут иметь денежную оценку.

Исходя из вышесказанного сказанного следует, что деловая репутация, являющаяся нематериальным активом юридического лица, подразумевает только положительную оценку и положительное общественное мнение о деловых качествах и профессиональной деятельности этих лиц.

Кроме того, отличительной чертой деловой репутации юридического лица являются особенности её защиты и невозможность компенсации морального вреда.

В пункте 11 статьи 152 Гражданского Кодекса РФ закреплено, что правила настоящей статьи о защите деловой репутации гражданина, за исключением положений о компенсации морального вреда, соответственно применяются к защите деловой репутации юридического лица.

Данное законоположение нашло одобрение в юридической литературе. Ранее судебная практика шла по пути признания за юридическим лицом права 
на компенсацию морального вреда. Так, в п. 15 Постановления Пленума Верховного Суда РФ от 24.02.2005 №3 указано, что правила, регулирующие компенсацию морального вреда в связи с распространением сведений, порочащих деловую репутацию гражданина, применяются и в случаях распространения таких сведений в отношении юридического лица. Однако такой подход был оценён законодателем как ошибочный.

Следует также поддержать названные выше изменения по следующим причинам. Согласно ст. 151 ГК РФ моральный вред представляет собой физические и нравственные страдания. Следовательно, не будучи живым существом, юридическое лицо ни нравственных страданий, ни тем более физических испытывать не может.

Итак, деловая репутация юридического лица является таким нематериальным благом, нарушение которого не вызывает возникновение морального вреда. Однако порядок её защиты подчиняется правилам, установленным для иных нематериальных благ.

Считается, что имидж является эмоциональным восприятием юридического лица его клиентами, контрагентами, а также другими участниками рынка. Имидж - это совокупность представлений, которые сформировались об организации в сознании людей.

Положительный имидж организации как работодателя способствует привлечению на вакантные рабочие места лучших специалистов, мотивирует работников работать с полной отдачей, снижает текучесть кадров. Безусловно, своему имиджу уделяют большое внимание не только «топовые» организации, фирмы-лидеры, а практически все фирмы, которым не безразлично их положение на рынке.

Тогда как репутация - это определенным образом формализованное восприятие характеристик, преимуществ и недостатков конкретной организации в бизнес-среде, стимулирует клиентов отдавать предпочтение именно ее продукции, а в конечном итоге, повышать ее прибыльность.

Таким образом, имидж является своеобразной «маской», созданной из эмоций и разрекламированности брендов, а деловая репутация — это то, что скрывается за этой маской — вся реальная сущность юридического лица. Итак, исходя из вышесказанного, репутация - понятие многогранное и сложное, все ее компоненты связаны между собой и только в комплексе могут обеспечить адекватное впечатление об организации. 
Деловую репутацию нельзя скопировать или заменить - это уникальная характеристика каждой организации, редкий и уникальный актив, который невозможно купить или получить без приложения определенных усилий. Она приобретается в процессе развития и является неотъемлемым элементом.

Подводя итог, следует сказать, что деловая репутация - это личное нематериальное благо юридического лица, которое формируется на основе существующей информации о престиже ее торговых марок, фирменного (коммерческого) наименования, деловых качеств, оценки потребителей и других внешних субъектов. Положительная деловая репутация юридического лица помогает увеличить его стоимость, тем самым влияет на эффективность деятельности.

1. Гражданский кодекс Российской Федерации от 30.11 .1994 года № 51-Ф3 (ред. от 03.07.2016) // Собрание законодательства РФ 13.01.1997, № 2.

2. Постановление Пленума Верховного Суда РФ от 24 февраля 2005 г. № 3 «О судебной практике по делам о защите чести и достоинства граждан, а также репутации граждан и юридических лиц // Сайт КонсультантПлюс, URL: http://www.consultant.ru

3. Имидж фирмы URL: http://knowledge.allbest.ru/management/ 3c0a65635b2ad68b5c43a89521206d27_0.html (дата обращения 09.03.2017 г.) 